\title{
The decline of the Kalahari wildebeest
}

\section{A. Spinage}

In the 1980s international publicity was given to the deaths of thousands of wildebeest in southern Botswana. The cause was their drought-induced migrations being prevented by the cordon fences erected to protect cattle from disease. While the mortalities may have accounted for 90 per cent of the wildebeest population since 1979, archive records from the 1920s and 1940s show that the decline started much earlier. Wildebeest were once so numerous in the southern Kalahari that local farmers regarded them as a menace, competing with cattle for grazing and transmitting malignant catarrh. Extermination programmes reduced the wildebeest population to such an extent that by 1961 the Botswana Government classified it as a game animal to be hunted only by licence.

\section{Introduction}

In 1980, at the beginning of a long drought period in Botswana, which ran from 1979 to 1987, a large but unestimated number of blue wildebeest Connochaetes taurinus died at Lake Xau in the north-east of the Kalahari Desert (Owens and Owens, 1980) (Figure 1). This was followed in 1983 by an estimated 50,000, and possibly as many' as 80,000 , further deaths (Parry, 1987). Although international attention was focused entirely on deaths in this locality, it was not the only place where wildebeest died. As Owens and Owens (1980) mentioned, $250 \mathrm{~km}$ to the south, from Lephephe to Dibete, thousands of wildebeest as well as hartebeest Alcephalus buselaphus died in 1980. Hundreds of carcasses were reported from Sojwe Pan (Kramer, 1980). Subsequent aerial survey estimates conducted from 1986 to 1990 suggested that more than 90 per cent mortality may have taken place among the wildebeest in the southern Kalahari population since 1979, when the population was estimated at 262,000 (DHV, 1980). This estimate was made at the peak of a run of good years and just prior to the drought, although it is recorded that 1979 was an exceptionally dry year and drastic redistributions of species took place. As a result, the estimate was a merged one without confidence intervals and should be treated with some caution.

There is no doubt that a major population crash did take place. This has been a recurrent phenomenon in Botswana (and no doubt formerly in neighbouring South Africa also) (Spinage and Matlhare, in press), resulting from the mean 20-year drought cycle to which this part of southern Africa is allegedly prone (Tyson, 1986).

A major migration of the wildebeest has not been shown to be an annual occurrence, but appears to take place only when the quality of the habitat falls below a certain minimum requirement, probably related to the amount of preformed water in the food. When this happens the movement of the wildebeest is believed to be from a wet season refuge, in an area characterized by numerous saline pans stretching in a broad band in a northwesterly direction across the middle of the southern Kalahari, known as the schwelle. From here they move north to north-east, a possible former northern migration to Lake Ngami or the Okavango Delta being severed since 1954 by an east-west veterinary cordon fence. This fence channels them eastwards to the region of Lake Xau (Williamson et al., 1988; Williamson and Mbano, 1988). Reports of mortality in 1963, when 300,000 are estimated to have died east of this area (Child, 1972), suggest that they once moved as far east as the 
Shashe River, but this movement may have related to a separate eastern population.

\section{Past records}

Archive records show that there was once a significant migration east and south-east from the southern Kalahari to the Molopo River. This first appears in reports in 1941 by the officer in charge of Werda police station. In a letter dated 28 July 1941 he stated that the area was being 'over run by great masses of Wildebeest all of which are moving down to the river looking for water ... The Wildebeest are in extremely poor condition and many of them are to be found dead on the Veld, some of them are so poor that they can only just stagger out of the river bank ...' (PrestonWhyte, 1941a).

On the 6 October 1941 the same writer reported: '... most of the Wildebeest seem to have moved off from the river. There are still, however, mobs to be seen and they are in a pityful [sic] condition. Many thousands of these animals died, no doubt, from thirst and starvation. As a result of the high death rate of game in the B.P. [Bechuanaland Protectorate] Kalahari area, beasts of prey are numerous ...' (Preston-Whyte, 1941b).

Another report, probably of 5 September 1941, commented: 'The wildebeest does not possess the drought resisting qualities of the other game of the Kalahari. This whole district is very dry and the wildebeest have been moving south in large numbers in search of water and more succulent grazing ... Large numbers have reached the Molopo ... Many dead and dying wildebeest were seen in and around mud holes in the river ... Thousands of gorged vultures were encountered along the river. In some cases they could scarcely raise themselves from the ground. One farmer had dragged 32 carcasses out of a muddy waterhole ...' (Anon., 1941).

Probably the same author of the above report, the Assistant District Commissioner for Tsabong, wrote on 10 January 1942:

'(b) The wildebeest trek South every winter [original emphasis] in large herds and many cross over into the Union between Tsabong and Khuis where there is no fence.

(c) It is only in times of drought that they force their way through the fences and mix with grazing stock.

(d) Of recent years bad droughts occurred in 1933, 1937 and 1941.

(e) When the wildebeest are on trek they move southwards steadily and can cover 20 to 25 miles in a day ....

(f) What steps do the Union Government [i.e. South Africa] propose to take to control the large number of wildebeest breeding in the Nosop Game Reserve? These no doubt constitute just as big a menace to the farmers of the Gordonia District as do our wildebeest to the farmers of Vryburg and Kuruman Districts. The Parks Board will probably say that they don't but nevertheless I gather that a good many trekked out last year' (Anon., 1942).

\section{Wildebeest destruction}

In October 1946 the question of destruction of wildebeest to control malignant catarrh in cattle was debated by the European Advisory Council (EAC, 1946), the problem area apparently being the Tuli Block on the Limpopo River. These were not reported as migratory wildebeest, but they may have been animals that stayed behind after migrating in the 1941 drought:

'The question of the destruction of wildebeeste has cropped up several times in the last three or four years. Many people are complaining. During the war years ammunition was very scarce and all game increased tremendously. Many farms which had been abandoned for some years have become absolute game reserves. Some farms which were never taken up before and which were never shot over much are also full of game and the particular species that is constituting a real nuisance is wildebeest ...' (Weatherilt, 1946).

'About twenty years ago the late $\mathrm{Mr} \mathrm{H}$. C. Weatherilt complained very bitterly in this Council of the same thing and asked for a free hand to destroy wildebeest ... we were 
allowed to shoot twenty-five, which is useless when the wildebeest are in hundreds coming and going as they like ...' (Glover, 1946).

The reference to 'about twenty years ago' referred to a brief report in the Minutes of the Council for 29 January-3 February 1923. The member for Tuli Block, H. C. Weatherilt, referred to a letter that the Resident Commissioner had received from the African Ranching Farms requesting permission to destroy wildebeest. He stated that it was impossible to carry out progressive farming where wildebeest abounded and that they should be taken from the list of protected game and treated as vermin, shot on sight without licence or permit (Anon., 1923). The question was raised again in 1931 (Anon., 1931) by a Mr Mason, who complained of cattle losses due to malignant catarrh:

There are hundreds of wildebeest. Last season I had considerably more wildebeest on my farm than I had cattle ... Last year we were asked to exterminate, and I understood you [Resident Commissioner] were doing this in conjunction with the Governments of

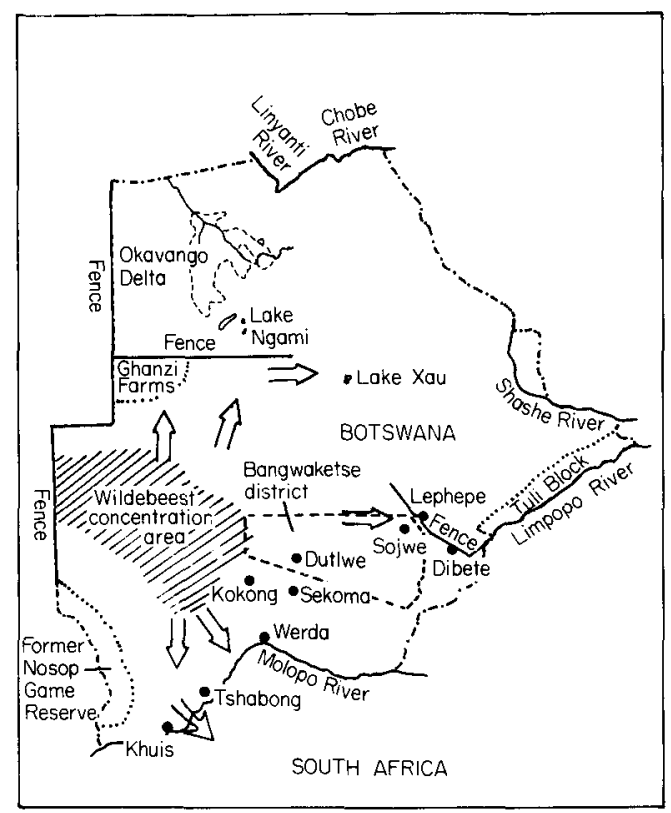

Figure 1. Botswana, showing places mentioned in the text, and movements of wildebeest.
Southern Rhodesia and the Northern Transvaal. As regards extermination of Protectorate wildebeeste in my district, I may say that not half the increase was destroyed. The Chartered Company agreed to the extermination, and on the British South Africa Company's ground 300 head were destroyed.'

It was not until 1953 that the landowners got their way and the wildebeest was downgraded from 'Large Game' to 'Small Game' throughout Botswana, which meant that it could be hunted without a licence. This had been applied from time to time for limited periods and in specified areas since 1924 to help control migrating wildebeest. The classification was revoked in 1961 when it became a game animal huntable only on a licence (Spinage, 1991).

\section{Hartebeest decline}

The decline of the hartebeest has received little comment, although there have been subjective estimates of 10,000 dying in the 1981-1987 drought against the Ghanzi farm fences. Aerial counts of hartebeest conducted in 1986-1990 suggest a 70 per cent decline. Although, being more drought-tolerant, they do not appear to have migrated in such large numbers as the wildebeest, a speaker in the Legislative Council in 1961 referred to hartebeest in 1959 and 1960 migrating in their thousands' just on the edge of the Bangwaketse District (Adams, 1961). The same speaker noted that in 1921-1922 from Sekgoma (Sekoma) to Kgokong and Dukwe (Dutlwe), you could travel for 40-60 miles $(64-96 \mathrm{~km})$ 'and never be out of view of game' trekking south-west or north-east. Although the species are not mentioned they would have been wildebeest, hartebeest, and perhaps eland Taurotragus oryx.

\section{Conclusion}

What is happening today in Botswana is what happened in, for example, Kenya in the 1920s, when the Rift Valley farms were fenced, pre- 
venting the migration of wildebeest and zebra. Such events went largely unreported at the time because there were then no vociferous international organizations to protest. As the archival records reveal, the decline of the Kalahari wildebeest has been engendered not solely by its nomadic habits in drought years being interrupted by cordon fences, but also as a direct result of its conflict with stock farming, and the decline appears to have been already well advanced by the 1960s. Such a process is considered to be inevitable in the face of modern agricultural development policies. The Kalahari wildebeest is a prime example of a species once considered to be so abundant as to be considered vermin, whose constant attrition in numbers has resulted in sudden near-extinction in parts of its range, or at least the altering of its dynamics from one of macro- gregariousness to one of sparsity. The wildebeest in the north of Botswana, which rely on the Chobe-Linyanti river systems, to which they still have access, have been relatively unaffected by the drought.

\section{References}

Adams, 1961. In: Hansard No. 3. Official Report of the Debates of the 1st. Session of the 1st. Legislative Council. Thursday 26 October, 1961. Botswana National Archives BNB 813.

Anon., 1923. Minutes of European Advisory Council. 29 January-3 February 1923. Mafeking, Mafeking Mail, Printers.

Anon., 1931. Minutes of European Advisory Council. 19-26 March 1931.

Anon., 1941. Partial report, probably of the Assistant District Commissioner, Tsabong, to W. F. Mackenzie, Deputy High Commissioner, Mafeking, ref. no. Kg. 264 of the 5.9.1941. Botswana National Archives S.49/5/1.

Anon., 1942. Assistant District Commissioner, Tsabong, to W. F. Mackenzie, Mafeking, 10.1.1942. Botswana National Archives S. 49/5/1.

Child, G. 1972. Observations on an Wildebeest dieoff in Botswana. Arnoldia, 31 (5), 1-13.
DHV. 1980. Countrywide Animal and Range Assessment Project. 7 vols. DHV Consulting Engineers, Amersfoort, The Netherlands.

EAC. 1946. European Advisory Council. Minutes of the 39th Session, 14-21 October 1946. (Bechuanaland).

Glover. 1946 In: European Advisory Council. Minutes of the 39th Session, 14-21 October 1946. (Bechuanaland).

Kramër, A. 1980. DDC/3 II (169). Letter from District Commissioner, Molepolole to Regional Medical Officer.

Owens, M. and Owens, D. 1980. Fences of death. Wildlife, June (214), 214-217.

Parry, D. 1987. Wildebeest Connochaetes taurinus mortalities at Lake Xau, Botswana. Botswana Notes and Records, 19, 95-101.

Preston-Whyte, R.N. 1941a. Letter of the 28.7.1941 to the Officer Commanding, Bechuanaland Protectorate Police, Lobatse. Botswana National Archives 3.49/5/1.

Preston-Whyte, R.N. 1941b. Letter of the 6.10.1941 to the Deputy Commandant, Bechuanaland Protectorate Police, Mafeking. Botswana National Archives 3.49/5/1.

Spinage, C.A. 1991. History and Evolution of the Fauna Conservation Laws of Botswana. Occasional paper No. 3. The Botswana Society, Gaborone.

Spinage. C.A. and Matlhare, J.M. In press. Is the Kalahari cornucopia fact or fiction? A predictive model. J. App. Ecol.

Tyson. P.D. 1986. Climatic Change and Variability in Southern Africa. Oxford University Press, Cape Town.

Weatherilt, H.C. 1946. In: European Advisory Council. Minutes of the 39th Session, 14-21 October 1946. (Bechuanaland).

Williamson, D.T. and Mbano, B. 1988. Wildebeest mortality during 1983 at Lake Xau, Botswana. Afr. J. Ecol. 26, 341-344.

Williamson, D.T., Williamson, J. and Ngwamotsoko, K.T. 1988. Wildebeest migration in the Kalahari. Afr. J. Ecol. 26, 269-280.

C. A. Spinage, The Bungalow, Steventon Road, East Hanney, Wantage, Oxon OX12 OHS, UK. 